ACTA $\mathbb{N E O P H I L O L O G I C A}$

UDK: [821.111.09:821.111(71).09]:2-185.2-053.2

DOI: 10.4312/an.50.1-2.95-135

\title{
Children Without Childhood: The Emotion- ality of Orphaned Children and Images of Their Rescuers in Selected Works of Eng- lish and Canadian Literature
}

\author{
Irena Avsenik Nabergoj
}

\begin{abstract}
This article deals with literary depictions of social, political, cultural and religious circumstances in which children who have lost one or both parents at birth or at a later age have found themselves. The weakest members of society, the children looked at here are exposed to dangers, exploitation and violence, but are fortunate enough to be rescued by a relative or other sympathetic person acting out of benevolence. Recognizing that the relationship between the orphaned child, who is in mortal danger, and a rescuer, who most frequently appears unexpectedly in a relationship, has been portrayed in narratives throughout the ages and that we can therefore speak of it as being an archetypal one, the article focuses especially on three novels by Charles Dickens - Oliver Twist (1837-1839), David Copperfield (1849-1850) and Great Expectations (1860-1861) - and in Fugitive Pieces (1996) by Canadian writer Anne Michaels. Charles Dickens earned the reputation of a classic writer through his original literary figures of orphaned children in the context of the rough capitalism of the Victorian era of the $19^{\text {th }}$ century. Such originality also distinguishes Anne Michaels, whose novel Fugitive Pieces portrays the utterly traumatic circumstances that a Jewish boy is exposed to after the Germans kill his parents during the Holocaust. All the central children's lives in these extreme situations are saved by generous people, thus highlighting the central idea of both selected authors: that evil cannot overcome good. Rescuers experience their selfless resolve to save extremely powerless and unprotected child victims of violence from life-threatening situations as a self-evident
\end{abstract}


moral imperative. Through their profound and deeply experienced descriptions of memories of traumas successfully overcome by central literary figures in a spirit of compassion and solidarity, Charles Dickens and Anne Michaels have left testaments of hope against hope for future generations.

Keywords: Charles Dickens, emotions, memories, Anne Michaels, holocaust, orphaned children, rescuers, trauma, adoption, the victory of good.

\section{INTRODUCTION}

In recent decades, the number of academic studies on the nature, role, education, and social position of children throughout history has increased, and there has been a parallel increase in fiction about children and about childhood. The history of children and childhood has birthed a new research area that offers critical insights into the human past by aligning itself with the global emphasis on interdisciplinary aspects as well as on contemporary social experiences. Thus, historians, beginning in the early 1960s, began to be interested in life experiences of the past, as revealed by family relations, religious experiences, various forms of education, along with experiences from working life, sports and leisure, and other areas. Adding their voices to historians' have been scholars from especially anthropology and sociology. Children and adolescents who, with rare exceptions, were excluded from active politics have become visible in studies focusing on family, school, as well as children working in factories and fields.

Investigating the presence of children in history became an exciting area for new social research in the late 1960s and early 1970s, the fruits of which studies were first extensively unveiled in the three books of the Encyclopedia of Children and Childhood: In History and Society (2004). Edited by Paula S. Fass, this monumental work includes no less than 445 expert articles dealing with childhood under various aspects in both historical and social terms; it has significantly changed the vision of history, while providing insights into how our ancestors thought about children in the past. Some other recent studies are relevant. ${ }^{1}$

Such research has turned to extremely diverse material that had previously been overlooked, including registers and wills, in poetry, novels and other works of literary fiction, in the thoughts of various philosophers and psychologists (from Plato and Aristotle through Erasmus, John Locke and Jean-Jacques Rousseau,

$1 \quad$ Cf. Coveney 1967; Pollock 1983; Cunningham 1995; Banerjee 1996; van der Geest 2004; Immel 2006; Stearns 2006; Georgieva 2011. A particularly crucial aspect of childhood is gender, and many new insights into childhood were made in terms of gender in the 1970s and 1980s. Cf. Prim. Fass 2004, Volume 1, xi-xv (Preface). 
Sigmund Freud, John Dewey and Jean Piaget); in diaries, pictures and photographs; in games and in many other material and immaterial forms from the past. Researchers are striving to understand children around the world, and their research thus extends to various parts of the world, all the way to Africa, Latin America, China, India and Australia; they also take into account great religious traditions, such as Judaism, Christianity and Islam, but also the early church fathers and the innovations of Protestantism, even as they pay attention to intercultural perspectives when it comes to names, sexuality, adolescence, and so forth.

In the West, childhood is presented in an in-depth manner that dates from ancient Greece and Rome, through the Middle Ages, through early modern Europe and European colonialism, right up to the modern world. Also considered are historical circumstances that are strongly reflected in fiction about children and childhood, including revolution, oppression and war. ${ }^{2}$

In this article, we proceed from the image of the child and childhood as an important literary theme, albeit while limiting ourselves to the image of the orphaned child in modern English and Canadian literature. Two authors who depicted orphans in particularly trying socio-political circumstances are the focus of this article - namely, Charles Dickens, who depicts children given over to criminals in poor parts of London, and Anne Michaels, who depicts the trials and tribulations of a young Jewish boy who experienced the violent death of his parents during the Holocaust.

\section{THE CHILD AND CHILDHOOD AS A LITERARY THEME}

In the last decades of the $19^{\text {th }}$ century, researchers increasingly discovered the crucial role childhood plays in defining and shaping culture. In 1960, the French historian Philippe Ariès, in his work L'Enfant et la vie familiale sous l'Ancien Régime, published in English in 1962 as Centuries of Childhood, encouraged historians to think about childhood ("as an invention, a historically driven phenomenon, not a transcendent category"). He argued that before the $17^{\text {th }}$ century childhood was invisible and that European society gave shape to childhood as part of a wider process of social differentiation. ${ }^{3}$ This raises the fundamental question of what the concept of childhood actually means. In dealing with different aspects of childhood, researchers usually define this word in relation to its opposite, adulthood.

2 The main research direction of looking various aspects of childhood is determined by attempts to answer the question of what childhood means. Researchers have most often defined this word in relation to its opposite, adulthood. Some have tackled the question of the essence or nature of childhood. 
By "childhood" they denote an earlier period of human life in which we acquire experiences and adopt behaviours that prepare us for the adult period of "active" life. Though the duration of childhood is not fully defined, it is also known that the concept of childhood has changed over the centuries - a change that also literary fiction has documented. From the treasure trove of world literature this article looks more closely at works of English and Canadian literature.

Childhood has long been one of the central themes in English literature. We see its presence in lyric poetry of the Elizabethan period, in such Shakespeare plays as Richard III, King John, Macbeth, The Winter's Tale, ${ }^{4}$ and in John Dryden and Alexander Pope. The importance of the subject of childhood greatly increased with the rise and development of the novel, gaining prominence through the $18^{\text {th }}$ century; in the $19^{\text {th }}$ and $20^{\text {th }}$ centuries it has stimulated seminal works that have proven crucial for a critical understanding of the literary production of individual periods. In the $19^{\text {th }}$ and $20^{\text {th }}$ centuries, also literature aimed at children was produced.

From the $18^{\text {th }}$ century forth, the child was either a subject or an object of popular writing. This writing mirrored the dichotomy of childhood, which was a symbol of growth and development on the one hand, and of the regression and ignorance of the world on the other. Authors such as James Janeway ( $A$ Token for Children, 1671-72), disseminated the doctrine of original sin through the $17^{\text {th }}$ century. They created a moralistic, religiously-oriented vision of childhood that was based on the theory of man's "Fall" and original sin, and looked on children with pessimism. At the same time, childhood was seen as the most decisive period in shaping the foundations of spirituality and constructing true faith.

In contrast to this type of thinking, $18^{\text {th }}$-century thinkers promulgated intellect and ratio as the highest of virtues. This century became a period of transition in which childhood became the highest symbol of the purity of nature, reason and the soul, as well as of the triumph of human congenital delicacy. Contrary to the thinking of previous centuries, childhood was perceived more positively and soon became a popular subject of the sentimental novel. The poverty and misfortune of innocent, virtuous children who possess a clear inner insight was the subject of many literary works of writers such as Elizabeth Bonhôte (in her 1769 Hortensia, or, The Distressed Wife). During this period, the idea emerged that in childhood the concepts of imagination, sensibility and nature were combined into one. In the literary representations of childhood, Jean-Jacques Rousseau and his novel Emile $(1762)^{5}$ proved strongly influential. Sentimentalism appeared not only in literature of the $18^{\text {th }}$ century but also in literature of the $19^{\text {th }}$ century, for example, in works by the writer George Eliot (1819-1880).

\footnotetext{
4 Cf. Partee 2006.

5 Cf. Georgieva 2011, 11.
} 
The theme of childhood in the $19^{\text {th }}$ and $20^{\text {th }}$ centuries was a prominent one in many authors. To mention just a few of them: William Blake (1757-1827), Songs of Innocence and of Experience $(1789,1794)$; William Wordsworth (17701850), "Ode: Intimations of Immortality from Recollections of Early Childhood" (1807) and "We Are Seven" (1789); George Gordon Byron (1788-1824), Don Juan (1817-1824); Charles Dickens (1812-1870), Oliver Twist (1837-1839), David Copperfield (1849-1850), Great Expectations (1860-1861); Thomas Hardy (1840-1928), Jude the Obscure (1895), Charlotte Brontë (1816-1855), Jane Eyre (1847); Henry James (1843-1916), What Maisie Knew (1897) and The Turn of the Screw (1898); Lewis Carroll (1832-1898), Alice's Adventures in Wonderland (1865), Through the Looking-Glass (1871), and Sylvie and Bruno (1889-93).

Important literary works about children and childhood also emerged in the United States and Canada, for example, in the works of Mark Twain (1835-1910) and William Faulkner (1897-1962). Twain's novels The Adventures of Tom Sawyer (1876) and the Adventures of Huckleberry Finn (1884) deal with stories of childbirth, the isolation of children in society and the pursuit of freedom in the face of social conformism. In Light in August (1932), meanwhile, Faulkner describes the poverty-stricken life of the orphan Joe Christmas.

In the $20^{\text {th }}$ century, the subject of childhood became popular in a number of very different genres, from C.S. Lewis's (1898-1963) descriptions of childhood however indirect - during wartime, to works composed by children themselves, even Anne Frank's (1929-1945) Diary of a Young Girl (1947).

Among more recent North American authors, we pay special attention here to Anne Michaels (1958), who in the novel Fugitive Pieces (1996) addresses the issue of saving a Jewish child named Jakob during the Holocaust, after the Nazis killed his father, his mother and his sister Bella. Michaels crafts the novel by focusing on the emotionally harrowing experience of the murder of the Jewish family and the story of the child, whose life was saved by Athos, a Greek archaeologist.

In the (necessarily limited) space of this article, we limit ourselves to assessing the literary renderings of child orphans in Victorian England in the three afore-mentioned Dickens novels, while also considering the emotional motivation for rescuers of Jews during the Holocaust as well as Jakob's emotionally-coloured memories, as depicted by Anne Michaels in Fugitive Pieces. Thus, we concentrate on the literary representations of child orphans who are saved by a benevolent adult. In the relationship between a helpless child and a rescuer, we see profound emotional bonds that go beyond the meaning of a single life story and that are, rather, a universal symbol of "hope against hope" in the most fragile of life's situations. Memories of traumatic childhood events engender deep feelings towards acts of sacrifice, which entails genuine human inclinations towards compassion and love. 


\section{ARCHETYPAL IMAGES OF THE CHILD-ORPHAN AND THEIR RESCUERS}

Louie W. Attebery, basing his insights on the similarities of structure and content he discerned in life stories of orphaned children and their rescuers, makes use of Jungian archetypes, among them, also that of the orphan:

Let me posit the notion that the orphan is one of these archetypes without now examining the rich psychological or emotional ontogeny of it. The orphan may be described as having lost physically or emotionally one or both biological parents and being endangered as a consequence; moreover, he usually seeks and finds companionship of some kind. He is frequently isolated from his place. Then depending upon how deeply he partakes of the heroic archetype - we are reminded by Jung that "clear-cut distinctions and strict formulations are quite impossible in this field" - the orphan may set himself to doing heroic deeds. Typically, as the orphan matures he experiences either an apotheosis or an atonement, in the sense of being re-united or re-identified as belonging and no longer alienated. In the beginning the orphan is likely to be innocent, i.e., nocence has not yet replaced ignorance; he does not willfully and knowingly sin. (Attebery 1970, 206-207)

Among ancient examples, Attebery cites the Bible stories of the "orphan" Adam after his expulsion from paradise, of Joseph of Egypt, whose brothers sold him into slavery, and of Moses, who was saved from certain death by the Pharaoh's daughter.

Such rescuer figures appear throughout all periods of human history and culture. We even talk about the archetypes of the child-rescuer relationship. Among the most famous examples of such an archetype is the biblical example of Moses, who, like all Hebrew boys, was sentenced to death by the Pharaoh. He was, however, saved by the Pharaoh's compassionate daughter, who violated her murderous father's command and thus exhibited a vanquishing nobility that transcended all racial, social and cultural limitations (Exodus 2:5-10).

The example of Moses, who was condemned to death by a nationalistically-minded ruler but who was saved through an act of natural kindness that has universal value, ideally fits the common ancient tradition of the ancient Middle East. According to this tradition, widows and foreigners received special protection from the supreme deity and great kings, meaning that providing such protection was considered a general injunction for all people. In Mesopotamia the protector of the weak was the god Shamash, in ancient Egypt it was the sun god Re or Amon-Re, in ancient Israel it was the Yahweh. As Charles Fensham argues,

Yahweh is described in Old Testament literature as the protector of the weak par excellence. With direct apodictic style of command and prohibition Yahweh 
takes the weak under his protection. This is one of the important ethical doctrines of the Old Testament, but definitely not unique in comparison with conceptions in neighboring cultures. The only basic difference is that Yahweh is regarded as the only protector. He is even placed in opposition to the gods of foreign nations and hailed as the only true Supreme Judge of the world (Ps. 82). (Fensham 1962,137-138)

Kings in all the civilizations of the ancient Middle East were considered direct representatives of God on earth. Because kings and lesser nobility often failed to observe the commandment to protect the weak, prophets arose to explicitly remind them of their task. The prophetic voice in Deuteronomy 10:17-18 says, "The Lord your God is God of gods and Lord of lords, the great God, mighty and awesome, who is not partial and takes no bribe, who executes justice for the orphan and the widow, and who loves the strangers, providing them food and clothing."

The prophet Isaiah, meanwhile, beseeches the following: "Learn to do good; seek justice, rescue the oppressed, defend the orphan, plead for the widow" (Isaiah 1:17). The prophets' words apply not only to rules but to all people. A profound awareness of the need to protect the weakest members of society is also prevalent in the Wisdom tradition. In Proverbs 23, 10, the anonymous author says, "Do not remove an ancient landmark or encroach on the fields of orphans, for their redeemer is strong; he will plead their cause against you."

Collective societies did not foreground protection of the weak, such as widows and orphans - hence the importance of morally-aware prophets and other humane individuals. Charles Fensham emphasizes that displaying such humanity towards the weak was "a common policy" in the ancient Middle East and notes that it reached its peak in the prophetic message of the Hebrew Bible:

In the Israelite community this policy was extended through the encouragement of the high ethical religion of Yahweh to become a definite part of their religion, later to be inherited by Christians and Muslims. (Fensham 1962,139)

\section{THE ORPHANED CHILD IN SELECTED WORKS OF ENGLISH AND AMERICAN LITERATURE}

The generous and noble rescuers of orphaned children in literature, which are often a reflection of real life in a depersonalized and often criminal society, are

6 The Bible quoted in this article is The Holy Bible containing the Old and New Testaments with the Apocryphal/Deuterocanonical Books: New Revised Standard Version. Nashville: Nelson, 1989. 
the foremost examples of this ancient moral tradition. ${ }^{7}$ Among modern American instances, Attebery lists Huck from Twain's novel Huckleberry Finn. William Blake (1757-1827) is the first major English literary creator to address the theme of the orphaned child. Blake's strongly symbolic poems show the contradictions between the time when the child experiences the immediacy of life from a state of innocence and when the child grows up to encounter the trials, suffering and brutality of society, and asks rhetorical questions. Particularly interesting is his depiction of a critical judgement of the role of patriarchal protectors, where, rather than natural intimacy, social and religious conventionality are at play, including in connection with various types of abusive behaviour towards children. Mariam Radhwi summarizes Blake's basic views on the role of human nature and the natural environment as follows:

Besides the natural world, nature in Blake's Songs includes human nature. Innocence focuses on innocent human nature and promotes a positive outlook of life, to the extent of accepting injustice and misery and emphasizing human love. Experience stresses humans' darker side, such as jealousy, hatred, and their potential for destruction. (Radhwi 2011, 217)

The poet George Gordon Byron (1788-1824) most concretely manifested his views on childhood in his great epic Don Juan (1817-1824). The poem's hero is an idealised individual of great talent, albeit one who despises society and social institutions. Don Juan is depicted as a wealthy orphan who suffers under a protective mother striving to keep him pure and to shelter him from maleficent influences. The character of Don Juan points to Byron's pessimistic character:

The hero here, Don Juan, is a precursor to modern existentialists, who argue that the feelings, thoughts, and emotions of the individual are where meaning is to be found. An existentialist worldview can lead to a nihilistic one - in other words, a world-view in which nothing has meaning. In Don Juan, for instance, Byron seems to believe that humans constantly live under the burdens of despair, emptiness, and futility. (DeRouen 2011,245)

The English novelist and poet Thomas Hardy (1840-1928) wrote very critically about Victorian society. Most of his characters are tragic individuals who struggle in the clash between their passions and their social circumstances. In the novel Jude the Obscure (1895), Hardy focuses his social criticism on the matter of sexuality and marital life. The main character of this novel is the orphan Jude from

7 The relation between helpless, unprotected children and a benevolent rescuer strongly evokes the New Testament allegory of the Good Samaritan (Luke 10,30-35). Cf. Welch 1999; Gribble 2004; Roukema 2004; James 2007. Cf. also the excellent article on the nature of empathy: Cavanagh 1995. 
the English countryside who dreams of an academic career. He travels to the city, which is most alluring to him, but soon has a love affair with Arabella, who is in search of a husband. When Arabella finds out that Jude will not be able to satisfy her material expectations, she leaves him. Jude then enters into a love affair with his cousin Sue, with whom he lives in an extra-marital relationship and has children. Not least on account of his conflicted nature, a series of critical situations occurs that precludes him from entering university.

Through Jude's story Hardy aims to show how social circumstances lead to homelessness, a nomadic existence, unemployment, poverty and ruin. The circumstances of the novel show "that class structure and moral code are not solely affecting the protagonists from without, but they are rather a part of the collective subconscious within the individual" (Schares 2011, 512). The course of the story demonstrates that

[a]though there seems to be nothing more desirable to both of them than being together, there are always events preventing this - up to the tragic ending. Why this has to be, the novel refuses a definite answer, but there is far more to it than foreshadowings of dark hereditary family pathology. The novel reaches deeply into the psychology of its protagonists and offers various explanations and hints. (Schares 2001, 512)

The question is whether social circumstances are truly the main reason why the dream of a young person cannot be realized. In this case, does the main reason not lie in the contradictory character of the protagonist himself, in the rash decisions and in the lack of purity such as that one sees in the character of Oliver Twist? If Jude did not have the fortune that Oliver Twist did, namely, of finding a rescuer who acts out of pure love, and a reliable advisor, it cannot be merely the result of social circumstances, but also of his inner strength in terms of achieving a stable life.

The American writer Mark Twain (1835-1910), in his novel The Adventures of Huckleberry Finn $(1884,1885)$, describes the adventures of the boy Huckleberry Finn, who became an orphan when his mother died and his father left him. He was adopted by the Widow Douglas. Throughout the work, the motif of the intense loneliness of an abandoned boy is repeated. Twain's next novel, The Adventures of Tom Sawyer (1876), has Tom as the main character:

The major character is Tom, who stands for the resourceful, clever, and courageous American adolescent who loves to break rules, face the unknown, and give full play to his impulses. Accompanied by Huck Finn, Joe Harper, and Becky Thatcher, he has to confront Injun Joe, who, in the end, is trapped in a cave and dies. Tom is supported by his generous aunt Polly and the towns people. (Sorop 2011, 1085) 
In both works the author describes the adventures of an abandoned child by highlighting the child's innocence. The child acquires life experience through situations that he does not choose himself, though each child also encounters people who show compassion and mercy.

William Faulkner's (1897-1962) novel Light in August (1932) is the story of Joe Christmas and his life path, on which he encounters both cruelty and understanding. His mother dies during childbirth, and with her death the child is struck by the cruel path of homelessness. When his grandfather Eupheus found out years before that his daughter had run away with a man and become pregnant, he did not want her to keep the baby. Thus, after the daughter's death in childbirth, he took the boy to the door of an orphanage, leaving him there on Christmas day (hence the name Christmas). Joe Christmas experiences a difficult life path of social isolation, which is made all the more so difficult because he is of mixed race. How cruel racial discrimination in the American society of his time was is shown when the white woman Joanna Burden was allegedly murdered because she did not cohort with white people but with black people. According to the judgement of the people, only a black man could have committed this murder. Parallel to Joe Christmas's story is that of the poor girl Lena Grove, whose parents died when she was twelve years old. She was rejected by her acquaintances after she became pregnant, though unmarried, and when the father, Lucas Burch, left her; however, others are merciful towards her in her time of distress:

Society, as this novel shows, can be cruel and heartless, particularly toward individuals who do not conform. But, as seen with Lena, that is not entirely true. Ultimately, the human heart has enough compassion so that society will not destroy itself. (Cornell 2011, 427)

\section{THE ORPHANED CHILD AND HIS RESCUERS IN THREE DICKENS NOVELS}

In three of his novels - Oliver Twist (1837-1839), David Copperfield (1849-1850) and Great Expectations (1860-1861) - Charles Dickens depicts in a similar way the figure of an orphaned child who is saved by good people from his brutal environment of heartless oppressors. In all three novels, Dickens reveals the obvious contradictions brought about by rough capitalism: on the one hand are ruthless owners of factories and estates, on the other, impoverished workers. The mass poverty of the majority of the population had serious consequences for many families, but the most affected were children who had prematurely lost their parents. In an atmosphere of unscrupulous capitalism, they experienced especially harrowing 
destinies. In the novel Oliver Twist, Dickens writes in the shadow of the publication of the Poor Law Amendment Act 1834, joining his voice to those of those who protested on behalf of the poor and to their defenders.

The story of the novel Oliver Twist depicts the harrowing life story of the eponymous boy of unknown birth whose identity is not revealed until near the end of the narrative. After the boy's mother dies in childbirth, Oliver is sent to a miserable orphanage, where he is often beaten. From there he is moved to an adult home, and after a while, Mr. Sowerberry, an undertaker, takes him on as an apprentice. After Oliver suffers an unbearable situation also during his apprenticeship, where he is beaten, he flees from the countryside into the unknown. For a while, he wanders the poorer quarters of London and survives by begging, until he is noticed by Jack Dawkins, nicknamed "the Artful Dodger," and introduced to his "benefactor," the Jewish exploiter Fagin. Fagin, in whose company are also the Artful Dodger, Bill Sikes and Sikes's loved one Nancy, earned his living through money brought to him by orphans whom he had steal and prostitute for him. Fagin and the members of his gang also attempt to turn Oliver into a thief, but Oliver is resolute and firm in his sense of what is honest, so they are unsuccessful in this.

When one day the Artful Dodger and Charley Bates rob old Mr. Brownlow of his handkerchief in front of a book stall, the Artful Dodger and Charley Bates manage to escape, while Oliver, who only happened to be with the young thieves, is captured and brought before the magistrate. Mr. Brownlow senses the boy's honesty and protects him, taking him into his care. But Fagin's gang tracks Oliver down and abducts him. They constantly endeavour to corrupt him, but the boy remains equally good in spite of all these experiences.

When Bill Sikes needs an agile assistant because he wants to break into a house, Fagin assigns this role to Oliver. On the night of the burglary, when Oliver has to climb into the house through a tiny window and open the house for the others, the butler Giles shoots him. The burglars Sikes and Toby Crackit flee in panic, leaving Oliver alone on the doorstep. But the owners of the Maylie household see innocence in the gentle child, protect him again and take him into their care; Oliver becomes very emotionally tied to his benefactors. However, the leader of the gang Fagin and Monks, also a member of the London criminal world, continue to pursue Oliver. Monks even attempts to erase all traces of Oliver's birth, receiving from the leader of the house in which Oliver lived a gold locket that belonged to Oliver's mother; he throws it into the river. In this way he, as Oliver's half-brother, wants to acquire all of the property that belonged to Oliver's father. When Nancy, who has in the meantime moved to Oliver's side, reveals Monks's secret to Rose Maylie, Sikes murders her with a knife on discovering her betrayal.

But the prosecution of Fagin's gang soon follows. Sikes hangs himself, and all the other members of the gang of burglars are caught. Of the young thieves, only 
Charley Bates repents. Fagin is sentenced to death by hanging, and the other boys are sentenced to forced labour. The novel ends happily. Oliver is adopted by the generous Mr. Brownlow, who uncovers the secrets of Oliver's roots. It turns out that Rose is the younger sister of his mother Agnes, meaning that she is Oliver's aunt; Monks disappears from Oliver's life and succumbs to a live of debauchery and crime. Diana Chlebek notes:

Dickens's treatment of the themes of childhood, survival, and work are among his greatest accomplishments in this work. Oliver Twist was the first British novel to focus on the character of a child and to give the English pauper child a voice. It thus has a special status in the history of British literature and culture. (Chlebek 2011, 341)

One side of reality is the unsustainable situation in a Victorian society that exploited poor children to serve the profits of the landowners, while depersonalizing them, closing all doors to them that might lead to a normal development and future, meaning that many children ended in misery. In extreme cases of being unprotected and in danger, the other side of reality is shown: compassion for the weakest that awakens in generous people who turn out to be rescuers and saviours. Oliver, however, is not depicted as just any orphan but as an exceptional example of an "angelic" child. That is precisely the decisive factor in why the "saviours" recognized in him a person worthy of trust and generosity. Generous people enter the picture when a child - a pure-hearted orphan - is most in need of compassion and a loving companion. That is why, the family hearth of the rescuers, so to speak, reveals the most profound of humanitarian emotions, which Dickens shows most subtly in this literary narrative.

Oliver's nobility is seen throughout the novel; it is reflected not only in his rejection of Fagin's criminal ways, but also in the boy's contact with various people and in the purity and good-heartedness of his thinking. For example, there is the scene in which Oliver, a few days after the failed attempt to break into a house, lies wounded by the house. The Maylie family takes pity on him, takes him in and thereby protects him against the hand of justice. In chapter 29, the author presented two ladies from this family: one old, the other young, the 17-year-old generous orphan, Miss Rose Maylie. It seems that the girl - an orphan, like Oliver - is portrayed with a similar subtlety in terms of her good-hearted, generous and gentle character, which may further reveal his strong affection for the poor, especially to orphans.

In chapter 33 the writer describes the circumstances of a sudden illness that befalls the orphan Rose. Oliver is compassionate and stands by her side. It seems inconceivable that she might die, and he tells Mrs. Maylie: "I am sure - certain 
- quite certain - that, for your sake, who are so good yourself; and for her own; and for the sake of all she makes so happy; she will not die. Heaven will never let her die so young" (Dickens 2008, 258). John Gordon reads Oliver's belief that Rose cannot and must not die as an infallible law of kindness: "Oliver's intuition cannot be wrong. His instinctive sense that Rose will live comes from a clairvoyant core. He knows this, and in knowing he effects it - works, in the physician's word, 'a miracle"' (Gordon 2011, 22-23).

In the final chapter Dickens describes a few moments from the lives of good people, from the lives of those who remain happy through all ordeals: Mr. Brownlow, who adopted Oliver and truly came to love him, and his late mother Agnes. Dickens concludes his book with a description of the happy and affectionate love which Oliver has received: "I have said that they were truly happy; and without strong affection, and humanity of heart, and gratitude to that Being whose code is Mercy, and whose great attribute is Benevolence to all things that breath true happiness can never be attained" (Dickens 2008, 439-440).

The personation of the Good in the character of Oliver Twist evokes the category of those exceptional personalities we like to deem charismatic. Dickens shows this charisma through aesthetic approaches that provide a sense of the functioning of the transcendent and the sublime. The figure of Oliver evokes the rich European tradition of art that arrives at the sublime. David Ellison, in his book Ethics and Aesthetics in European Modernist Literature: From the Sublime to the Uncanny (2004), addresses the complex relationship of ethics and aesthetics in the literature of Romanticism and Modernism. Stephen Jaeger, meanwhile, in his book Enchantment: On Charisma and the Sublime in the Arts of the West (2012), masterfully deals with cases that reveal the possibilities of artistic representation of the charming, the charismatic and the sublime in texts and images. ${ }^{8}$

Dickens' work David Copperfield is one of the first novels to show with such psychological profundity and with such great sympathy the thoughts and feelings of the child in his development from early childhood to adulthood. It begins with the description of the idyllic childhood of the young boy David who, born six months after the death of his father, had a rather sanguine existence with his loving mother and the servant Clara Peggotty.

But the happiness of his early childhood is destroyed through his mother's second marriage, to Edward Murstone, who is not inclined to the child. He sends David to Peggotty's relatives in Yarmouth. When he returns, he is subjected to the emotional and physical cruelty of his new father, who also tyrannizes David's

8 Roland F. Anderson, in the article "Structure, Myth, and Rite in Oliver Twist" (1986), uncovers in the novel Oliver Twist a possible influence on the author of the biblical Eden whereby Christian spirituality subtly merges with the world of the fairy tale to lead to a happy end for the main hero. 
poor mother. When David tries to stand up to him, he is sent to the Salem House boarding school run by the sadistic teacher Creakle.

When David's mother also dies, Mr. Murdstone sends him to work at a wine merchant in London. But David's landlord Wilkins Micawber is arrested for debt and sent to jail for several months. During this time nobody cares about David, so he decides to escape from London. He finds refuge in Dover with his only cousin, the eccentric, but kindly Aunt Betsey Trotwood. In spite of Murdstone's attempt to regain custody over David, she does give him up but provides a normal life and good education for him. He is sent to a better school under the leadership of Dr. Strong, who is found of instilling honour and self-confidence.

David becomes a successful and respected writer. His first marriage to the lovely but naïve Dora Spenlow is an unfortunate one, as she dies soon after the wedding. After his wife's death David lives for a time in Switzerland, and after returning to England he meets his second wife, Agnes Wickfield. The love is mutual. In his marriage with the benevolent and wise Agnes he finds true happiness and the two have five children. In the novel David Copperfield (which was his favourite of his novels), Dickens includes so many memories of his own unhappy childhood that the story is redolent of autobiography. Diana Chlebek notes,

[t]he book's opening chapters are remarkable for the way they depict David's child's-eye view of his immediate environment, especially through the eccentricities of a toddler's thought processes. The adult narrator also vividly recalls the emotional abandon that his childself shares with his young mother, who assumes the role of a delightful playmate rather than that of a dependable parent. Although David's early years appear idyllic, the narrator emphasizes the insecure foundation of his childhood by describing his anxieties about his dead father and his uncanny child's observations about his mother's frail and unstable nature. (Chlebek 2011,334-335)

In the novel, Dickens paints a subtle picture of the natural need of a child for emotional benevolence in his darkest moments of childhood, at a time when he lost the replacement family of the Micawbers who gave him a room, care, but above all emotional support.

David shows a sign of adulthood when he is able to decide to travel, on foot from London, to his aunt in Dover. His aunt Betsey becomes his true rescuer, for she adopts him and provides him with a stable life with the possibility of unhindered education. David's fortunate salvation with his benevolent aunt is all the more emphasized because many of the other children David knew were broken by life because they did not find a rescuer in childhood who might provide them with moral and material support. The consequences in their later life are shown as 
emotional anxiety and incapacity for harmonious marriage and for the stabilization of their careers.

In the novel Great Expectations, the story of which takes place in Kent and London from the beginning to the mid $-19^{\text {th }}$ century, Dickens penetrates deepest into the psychology of the orphaned child in his personal growth and development from earliest childhood on. The main character of the novel, a seven-year-old orphan named Pip, lives with his older sister and her friendly husband, Joe Gargery, a blacksmith by profession, after the death of their parents. When one evening before Christmas at the cemetery he cries for his parents, whom he never knew, he meets the convict Magwitch. At Magwitch's request, Pip brings him food, but the prisoner is soon caught. Magwitch has to go into exile in Australia, but at all times he maintains a very deep and emotional attitude towards the orphan Pip.

When he visits the wealthy Miss. Havisham, Pip falls in love with her adopted daughter, Estella, who is cold and spiteful. Nevertheless, he falls in love with her and dreams that he will become a wealthy gentleman who will be worthy of her. At first, he feels that Miss. Havisham is very much inclined to him, though at some point Pip must recognize that she aims for him to be a lowly worker in the family business. However, in the forge, Pip is unhappy and strives to improve his lot. One day the rich lawyer Jaggers appears with the unusual news that a secret benefactors has left Pip a great fortune. Pip has to depart immediately for London and begin his education there. He himself assumes that his secret hopes have come true and that his secret benefactor is old Miss. Havisham, and that she wants him to marry Estella.

In London, Pip meets the young Herbert Pocket and Jaggers's clerk Wemmick. The education continues under the mentorship of Matthew Pocket, Herbert's father. A few years later, Pip finds out that his benefactor was not Miss. Havisham but Magwitch, who was once guilty of a crime and sentenced to deportation to Australia. Pip's friendliness, when he was still a child, prompted the convicted person to dedicate his life to making a gentleman of Pip with the help of the wealth he earned in Australia.

The story of Pip's childhood shows no sign of hope at the start. In contrast, Magwitch in exile maintains a very strong hope, reinforced by his emotional relationship with Pip. At some point he breaks the law and returns to England. Estella disappoints Pip's hopes of getting married, and marries Bentley Drummle.

Pip realizes that he has set his hopes on people who could not fulfil them, and that he has rejected his true benefactor Magwitch, whose sadness Pip mitigated after the convict was rejected by his homeland. In this emotional state, he makes a plan to help Magwitch escape, though Magwitch loses his life in the attempt. Dickens's descriptions of the contrast between Pip's expectations of Miss. Havisham and Estella on the one hand and the resistance to the convict Magwitch 
on the other lead Pip to the recognition that happiness is not guaranteed by those who live in prosperity but by those who themselves have been deprived in one way or another.

\section{EMOTIONALITY OF CHILDREN DURING WAR AND MEMORIES OF POST-WAR TRAUMA}

The emotionality of children during a period of war is as complex a phenomenon as that of human nature at all times from birth to death. Anthropologists, psychologists and researchers, as well as artistic performers, creators of human life, culture and religion and people from many other professional and scientific fields provide many general insights into the matter. The world of the emotions, which in various shades and contrasts are reflected in the war situation in interpersonal relations, are perhaps most suggestively revealed in a number of autobiographies, diaries, memories and fictional literary works. A general study of the theory of children's emotionality in war situations is discussed in Children and War: A Historical Anthology (2002). This book offers a historical context for periods when children were caught up in war. It shows them at home, during their active participation on the front and in other circumstances.

Affiliation with a race, nation, culture and religion significantly increases the complexity of children's emotionality during the trials and tribulations of war on account of cultural, religious, educational and other surroundings. The emotionality of children is also strengthened by the appearance of rescuers who, in attempting to rescue children, also themselves enter into conflict situations. To better understand the literary approach of the Canadian author of Jewish heritage Anne Michaels in the next section of this paper, here we devote particular attention to the aspect of the emotionality of Jewish children in the period of the war as well as to their memories of trauma after the war.

Jeffrey T.Zalar, in his article "Holocaust"(2004), cites the various emotional and spiritual shocks suffered by Jewish children during the period of the Holocaust: hunger, sickness, forced labour, murder and the loss of parents. Older children took care of younger children. Parents attempted to hide their children from the Nazis in barns, pantries, basements, coal containers, cupboards, in walls, chimneys, forests, caves and elsewhere. Forced labourers attempted to hide their children in factories. Some children were hidden, under the threat of death, by non-Jews who claimed them as their own, and hundreds were hidden in Christian schools and monasteries. In each case the children experienced fear and loneliness.

The most radical Nazi killing campaign was during the occupation of Russia in 1941. For this destruction the Nazis organized a reserve army and police and 
paramilitary groups of non-Jewish residents. In the initial phase of the Second World War, the Nazis left the children alive after killing their parents, placing the children in local buildings. Because this led to an unbearable and uncontrollable situation with orphans, they started to massacre them. Elsewhere during the occupation of Russia they recruited the healthy ones for forced labour, but immediately killed the sickly, and later they also killed their parents. After 1942, the Nazis deported also Jews from Western European to the East. Most of the children were killed or murdered in gas chambers upon their arrival in the camps. Healthy and slightly older children were sent to concentration camps for forced labour. At the concentration camp in Auschwitz, about 3000 twins were abused for horrific medical experiments under the guidance of SS doctor Josef Mengele.

The complexity of emotionality felt by Jewish children is shown in the collection Jewish American and Holocaust Literature: Representation in Postmodern World, which was edited by Alan L. Berger and Gloria L. Cronin (2004) - especially in Berger's chapter "Hidden Children: The Literature of Hiding" (pp. 13-53). Three years later Diana L. Wolf published her important study about: Beyond Anne Frank: Hidden Children and Postwar Families in Holland (2007). In the same year Mark M. Anderson's article "The Child Victim as Witness to the Holocaust: An American Story?” (2007) appeared.

Berger, in his contribution "Hidden Children: The Literature of Hiding," explores the various aspects of searching for identity experienced by children who lost their parents in the Holocaust and who had to go into hiding at rescuers' because of the great danger of being discovered by the Nazis. These children experienced great trauma, since they became orphans. They lived in constant fear and only a small percentage of the children was fortunate enough to survive:

Approximately 1.5 million of the 1.6 million prewar Jewish child population in Nazi-occupied Europe were murdered. This means that only 6 to 7 percent of Jewish children lived through the Shoah. Hidden in a variety of places including farms, barns, cellars, pigsties, convents, and monasteries, their hiding experience invariably robbed them of their childhood. (Berger 2004, 13)

From Stacy Cretzmeyer's Your Name Is Renée (1999) and Elisabeth Gille's Shadows of a Childhood (1998), Berger asserts:

Four themes emerge from these written works: fear of abandonment by parents and by God; the psychic disorientation imposed by a new identity necessitated by the invention of a life history in order to survive; silence and a lack of understanding of why this happened to them; and a search for justice. While these themes do not receive equal weight in the works under discussion, each form a part of the mosaic of the legacy of hiding. (Berger 2004, 13-14) 
Among children who saved themselves by hiding in their rescuers' hiding places, the question of identity proves particularly complex. The saved Jewish children found themselves in paradoxical circumstances, since they were torn from their original family circle and moved into an environment that was mostly not Jewish, but Christian. In the case of Christian rescuers, there was often an internal struggle between feelings of pure altruism and inherited anti-Jewish prejudices. Somewhat older children still recalled Jewish rituals from within family circles and from the broader environs of the Jewish community. In the Christian environment of their new parents they were now witnessing Christian rituals, a Christian religious view, and an ambivalent attitude towards Jews. The consequence of this was that some Jewish children sooner or later reclaimed their Jewish identity, while other rejected Judaism and accepted Christianity.

Ella Mahler, in "About Jewish Children Who survived WW II on the Aryan Side," (p. 49) cites the example of the nine-year-old Jewish girl who exclaims, "The Jewish God killed my parents. He burned my home. Jesus Christ saved me."

The great danger that the Nazis and their collaborators might discover the children in their hiding places forced the parents (if they were still alive), the rescuers of the children, and the children themselves to consciously and unconsciously remain silent about their existence:

Hidden children had to embrace silence, seek memory, and comprehend their identity in a morally distorted and chaotic world bent on their destruction. Discouraged from speaking about their experiences after the war, the hidden children continued their silence.

Many hidden children have an understandably ambivalent relationship to Jewish identity. Being Jewish during the Holocaust meant being a target of murderers and being deprived of elemental happiness. Being driven into hiding because of their Jewish birth meant concealing their true identity. (Berger 2004, 15)

The other side of the truth about the subsequent traumas of Jewish children who had been in Christian hiding places was the intolerance of the Jewish community itself towards children that converted to Christianity. For example, Saul Friedländer relates that he was "beaten by Jewish children because they thought I was different from them. So I belonged nowhere” (Friedländer 1979, 45).

Just how self-understood it was that those involved in the hiding of Jewish children kept silent about their existence is especially dramatically confirmed in the number of death sentences of rescuers who were discovered. Elisabeth Gille, in her novel Shadows of a Childhood (1998), highlights on the example of Léa Lévy, a girl with a Jewish name who was hidden by nuns in Bordeaux the dangers to which rescuers were exposed. This Jewish girl went to their school soon after the Nazis arrested and deported her parents: 
The child's rescuer, Pierre, is himself the brother of Sister Marthe, one of the convent's nuns. Shortly after Léa's arrival, Pierre is murdered by Nazis. Additionally, the author underscores the hardships faced by all parties in the hiding situation. For example, both Léa and the nuns had meager food rations, inadequate clothing, and lived under constant stress owing to the omnipresent danger of raids and arrest. (Berger 2004, 23)

It is also understandable that the emotionality of children who were saved through hiding bred a galvanized sense of justice which manifested itself in the post-war period. Children thus affected very closely followed post-war judgements against Holocaust perpetrators and were clearly on the side of justice. It is therefore even more obvious that their psychological trauma was never completely overcome.

At the end of his chapter, Berger summarizes some important effects of the intense emotionality of children who were saved by going into hiding, and of all the others who participated in saving them:

Memoirs by hidden children attest to their determination to move out of the shadows and into the light of shared experience. Furthermore, these memoirs are an attempt to retrieve a fragment of their lost childhood in spite of the trauma that accompanies memory. (Berger 2004, 27)

Another important emotional effect is the recognition of the power of kindness shown by rescuers:

Because they were chosen for life and not selected for death, their testimony leads us to examine the actions of those whom Lawrence Baron terms "the moral minority," those who engaged in rescue behavior. What prompted those who helped? Can their behavior be emulated? Is altruism an innate or a learned behavior? What of the religious ambiguity felt by certain of the helpers?

... Goodness is a greater mystery than evil. Recognizing that one person's actions can literally save a life prompts us to seek alternatives to following genocidal orders. Moreover, by recognizing goodness we develop a more genuine and far-reaching understanding of the nature of heroism and the heroic.... (Berger 2004, 27)

In an emotional aspect, we are most shocked by the opposition between the workings of evil and the goodness of the heart. It is shocking to recognize the immense extent of abuse of children carried out by individuals or groups:

What greater abuse can be visited upon a youngster than murdering his or her parents and sending the child away from all that is familiar and nurturing? 
Nazism was in fact a deadly assault on the notions of parenting and childhood itself. It is important for hidden children to work through their Holocaust memories and thus learn how to mourn their losses. Further, it is also vital to acknowledge that children who were abused in their hiding homes do not necessarily become abuser themselves. Perhaps the most important legacy of hidden children will occur when people who hear their testimony seek to build a moral society that cherishes, rather than murders, children. (Berger 2004, 28)

Diane L. Wolf, in the book Beyond Anne Frank: Hidden Children and Postwar Families in Holland (2007), describes a few examples of Jewish orphans in the periods during and after the war in the Netherlands. A sociologist, the author is more interested in the real stories of traumatized children than in the idealized diary of Anne Frank. She attempts to make the survivors come alive in the search for a new identity during the post-war period. The book is based on the testimonies of 70 Jews who survived the Holocaust by hiding out in non-Jewish families in the Netherlands. She summarizes the basic content thus:

Hidden children were given up by their parents, usually as young children some as young as a few hours old, often to strangers who delivered them to non-Jewish Dutch families. They were openly or clandestinely hidden anywhere from one night to several years. Most children hid in more than one place, yet quite a few experienced the stability of being in one family for a long period. Their time in hiding was a period of danger when they were forced to adopt new identities that did not reflect their Jewish past and to adapt to the ways of a new family. In some cases, these children formed strong emotional attachments to their hiding families and felt it was the best period in their childhood; in most cases, however, close attachments did not develop. (Wolf 2007, 329-330)

Because these children were taken in and hidden during the war, these children experienced more severe trauma after the war than during it. At that time, the real trauma began for them, as children experienced a double identity in their conflicted interests, and they were also affected by post-war anti-Semitism, which also in the Netherlands showed a different face than that which can be read from Anne Frank's diary.

\section{THE EMOTIONALITY OF AN ORPHANED JEWISH CHILD IN ANNE MICHAELS'S NOVEL FUGITIVE PIECES}

The contemporary Canadian poet and writer Anne Michaels was born in 1958 in Toronto, Canada, the daughter of a Polish Jewish father. She gained the attention of the international public through her poetic style which maintains a balance 
between technical precision in presenting stories and profound meditation marked by a strong sense for humanity. Her works have been translated into more than forty-five languages and she has received a number of international awards, including the Orange Prize, the Guardian Fiction Prize, the Lannan Award for Fiction and the Commonwealth Poetry Prize. She became most famous with her novel Fugitive Pieces (1996), which was well received by critics and literary historians.

In Fugitive Pieces, her first novel, Anne Michaels engaged with a complicated range of interrelated questions. These questions relate to history, the role of the environment in which one lives, identity, pain and grief: "All of the pieces are in some way related to the tension between ambition and survival, in all senses of the two concepts - artistic, psychological, spiritual, and literal" (Wiman 2001,90). She lay the foundations for her future works in her first prose effort, in which she examines the relationship between history, memory and questions about how people remember past events and how they can, through love, overcome traumatic mental and spiritual conditions. Victoria Nesfield and Philip Smith, in their article "Holocaust Literature and Historiography and Anne Michaels' Fugitive Pieces" (2013), argue that

Anne Michaels' Fugitive Pieces is a work of historical fiction in the genre of Holocaust literature. This genre is problematic in that writers (either "survivors" or those who were not there) are compelled to engage with the events of the Holocaust whilst lacking the authority to do so. Michaels uses fiction as a means to examine the multitude of ways in which events can be communicated and given meaning. She does not present history in binary terms of "truth" and "untruth" but as a battleground over the meanings with which recorded events are imbued. The preservation of meaning in events requires not only alternative historiographical works, but alternatives to hegemonic historiography such as music and geography. (Nesfield and Smith 2013, 24-25)

At the heart of this poetic novel in two parts are two heroes, both Jewish and of Polish heritage: Jakob Beer and Ben. The point of departure in terms of memory in the first part is an event that took place in Poland in 1941, when the Nazis killed the parents of seven-year-old Jakob Beer and took away his sister Bella; Jakob hid himself before running into the woods near the archeologic site of Biskupin. There he was found by the Greek geologist Athos Rousoss and smuggled away to the rescuer's home in Greece, on the island of Zakynthos, where the two somehow survived until the end of the war, when he and Jakob Beer moved to Toronto, Canada. There, Athos received a post as a lecturer, while Jakob devoted himself to studying. After Athos's death Jakob moved into Athos's parents' home on the island of Idhra and wrote down the memories that had prevented him from sleeping. Jakob dies in 1993 in a car accident in Athens. 
The hero of the second part of the novel is the Jewish Canadian professor Ben, who is an admirer of Jakob's poetry. Ben gets to know Jakob Beer through his professor Maurice, with whom he is friendly. He makes such a strong impression on Ben that he begins to become interested in his work. That helps him uncover suffering such as that with which Jakob had to deal in the past. Ben is also marked by the weight of the Holocaust, though he has his wife Naomi standing by his side. After Jakob's death Ben travels to the island of Idhra and searches there for Jakob's diaries, which serves as a basis for Fugitive Pieces.

With her novel, Anne Michaels recalled the memory of the precious lives and the suffering of many Jews, such as Jakob Beer, his sister Bella, and his mother and father, Ben and some others. Many lost their lives in the Holocaust, and only a few, through the help of exceptional persons the likes of the Greek geologist Athos from Anne Michaels's novel, managed to escape certain death. These generous people, through their love as well as material and spiritual help, sought to provide the survivors with security and help them overcome overwhelming memories, maltreatment, and thus to start a new life.

Alongside these preserved memories there are many diaries, manuscripts, testimonies and memoirs that were lost or destroyed during the Second World War; "Some of these narratives were deliberately hidden - buried in back gardens, tucked into walls and under floors - by those who did not live to retrieve them" (Michaels 1996, 9). Some stories are retained only by memory, never having been written down or spoken, while other memories, such as Jakob's in Anne Michaels's novel, were discovered by chance.

The novel refers to the childhood memories of Jakob Beer when he, a seven-year-old child, was saved by the geologist Athos Roussos near the archaeological remains at Biskupin while he was fleeing the German soldiers who had just killed his parents and taken away his fifteen-year-old sister. Jakob made it through a German patrol in a car driven by Athos and hidden under a blanket. Athos, meanwhile, tricked the Germans by feigning illness. The horrific experience of Jakob's family tragedy is always with him. The first-person narrator recalls the events this way:

My sister had long outgrown the hiding place. Bella was fifteen and even I admitted she was beautiful, with heavy brows and magnificent hair like black syrup, thick and luxurious, a muscle down her back. "A work of art," our mother said, brushing it for her while Bella sat in a chair. I was still small enough to vanish behind the wallpaper in the cupboard, cramming my head sideways between choking plaster and beams, eyelashes scraping.

Since those minutes inside the wall, I've imagined that the dead lose every sense except hearing. 
The burst door. Wood ripped from hinges, cracking like ice under the shouts. Noises never heard before, torn from my father's mouth. Then silence. My mother had been sewing a button on my shirt. She kept her buttons in a chipped saucer. I heard the rim of the saucer in circles on the floor. I heard the spray of buttons, little white teeth.

Blackness filled me, spread from the back of my head into my eyes as if my brain had been punctured. Spread from stomach to legs. I gulped and gulped, swallowing it whole. The wall filled with smoke. I struggled out and stared while the air caught fire.

I wanted to go to my parents, to touch them. But I couldn't, unless I stepped on their blood.

The soul leaves the body instantly, as if it can hardly wait to be free: my mother's face was not her own. My father was twisted with falling. Two shapes in the flesh-heap, his hands.

I ran and fell, ran and fell. Then the river: so cold it felt sharp.

The river was the same blackness that was inside me; only the thin membrane of my skin kept me floating. (Michaels 1996, 9-10)

From this terrible experience forth, Jakob's memories are indelibly overwhelmed by thoughts of the dead:

The dead passed above me, weird haloes and arcs smothering the stars. The trees bent under their weight. I'd never been alone in the night forest, the wild bare branches were frozen snakes. The ground tilted and I didn't hold on. I strained to join them, to rise with them, to peel from the ground like paper ungluing at its edges. I know why we bury our dead and mark the place with stone, with the heaviest, most permanent thing we can think of: because the dead are everywhere but the ground. I stayed where I was. Clammy with cold, stuck to the ground. I begged: If I can't rise, then let me sink, sink into the forest floor like a seal into wax. (Michaels 1996, 10)

Jakob is most struck by the disappearance of his beloved sister Bella, and he dreamed about her during the day when he slept buried in earth, and at night, as he walked on through the woods. He remembers her reading her favourite novels by Romain Rolland and Jack London, and it was unbearable for him that he could no longer hear her: "Filled with her silence, I had no choice but to imagine her face" (Michaels 1996, 11).

One grey autumn day Jakob, at "the end of his strength" and hungry, stopped just a few metres away from where Athos had picked up the weeping boy and carried him under his heavy coat and driven away with him. Jakob recalls: 
For miles through darkness in the back seat of the car, I had no idea where we were or where we were going. Another man drove and when we were signalled to stop, Athos pulled a blanket over us. In Greek-stained but competent German, Athos complained that he was ill. He didn't just complain. He whimpered, he moaned. He insisted on describing his symptoms and treatments in detail. Until, disgusted and annoyed, they waved us on. (Michaels 1996,13)

During the drive the feverish Jakob thinks about his sister Bella and about his best friend Mones, though his thoughts are also ineludibly tied to Athos: "But Bella clung. We were Russian dolls. I inside Athos, Bella inside me" (Michaels 1996, 13).

Athos promises shelter to the young boy Jakob, who lies hungry and worn out in his car:

Athos said: "I will be your koumbaros, ${ }^{9}$ your godfather, the marriage sponsor for you and your sons...."

Athos said: "We must carry each other. If we don't have this, what are we...." (Michaels 1996, 13)

As Jakob approaches the home of his rescuer Athos and the faraway island of Zakynthos, his memories conjure up again and again images of his mother, father and sister Bella. Jakob says:

I watched Athos reading at his desk in the evenings, and saw my mother sewing at the table, my father looking through the daily papers, Bella studying her music. Any given moment - no matter how casual, how ordinary - is poised, full of gaping life. I can no longer remember their faces, but I imagine expressions trying to use up a lifetime of love in the last second. No matter the age of the face, at the moment of death a lifetime of emotion still unused turns a face young again. (Michaels 1996, 14)

Eventually Jakob adapts to the new surroundings, but the whole time he recalls the traumatic event of the murder of his mother and father as well as the disappearance of his sister Bella; he does not know where she is, where and how or even if they murdered her or even whether she is still alive. Also on Zakynthos he lives in fear:

On Zakynthos we lived on solid rock, in a high and windy place full of light. I learned to tolerate images rising in me like bruises. But in my continuous expectation of the burst door, the taste of blood that filled my mouth suddenly,

9 This Greek word refers to an individual who exchanges crowns over the betrothed in the Greek Orthodox wedding ceremony (along with other roles). 
many times a day, I couldn't conceive of any feeling stronger than fear. What is stronger than fear; Athos, who is stronger than fear?

On Zakynthos I tended a garden of lemon balm and basil in a square of light on the floor. I imagined the thoughts of the sea. I spent the day writing my letter to the dead and was answered at night in my sleep. (Michaels 1996,15)

The rescuer of the orphan Jakob - named Athos or Athanasios Roussos - is an extremely warm man who cares for Jacob as if he were his own son and reveals to him, through his immense knowledge, wisdom and spiritual depth, new life horizons, new intellectual directions in reflecting on the relationship between life and death, to living and dead nature, to time and history, to the past and the future. Athos offers him the beginning of a new life: "Even as a child, even as my bloodpast was drained from me, I understood that if I were strong enough to accept it, I was being offered a second history" (Michaels 1996, 20).

Jakob has the child's devotion to his caregiver:

To share a hiding place, physical or psychological, is as intimate as love. I followed Athos from one room to the other. I was afraid, as one who has only one person to trust must be afraid, an anxiety I could only solve by devotion. I sat near him while he wrote at his desk, contemplating forces that turn seas to stone, stone to liquid. He gave up trying to send me to bed. Often I lay at his feet like a cat, surrounded by books piled ever higher on the floor beside his chair. Late at night, while he worked - a solid concentration that put me to sleep - his arm dangled like a plumb line. I was soothed by the smells of bindings and pipe tobacco and the weight of his safe, heavy hand on my head. His left arm reaching down to earth, his right arm reaching up, palm to heaven. (Michaels 1996, 15)

This admiration gives rise to the utmost respect that Athos feels for the young boy Jakob. Athos did not want Jakob to forget his own language, so he had to repeat the Hebrew alphabet, but at the same time Athos also taught him Greek and English:

Athos didn't want me to forget. He made me review my Hebrew alphabet. He said the same thing every day: "It is your future you are remembering." $\mathrm{He}$ taught me the ornate Greek script, like a twisting twin of Hebrew. Both Hebrew and Greek, Athos liked to say, contain the ancient loneliness of ruins, "like a lute heard distantly down a hillside of olives, or a voice calling to a boat from a shore." (Michaels 1996,17)

Jakob longed, "to cleanse [his] mouth of memory" (Michaels 1996, 17) and feel the new memories as truly his own even when speaking in what was for him a foreign language. Recalling Athos, Jakob says, 
By early morning Athos was often close to tears of admiration for his brave lineage, or for the future: "I will be your koumbaros, your godfather, the marriage sponsor for you and your sons.... We must carry each other. If we don't have this, what are we? The

spirit in the body is like wine in a glass; when it spills, it seeps into air and earth and light ... It's a mistake to think it's the small things we control and not the large, it's the

other way around! We can't stop the small accident, the tiny detail that conspires into fate: the extra moment you run back for something forgotten, a moment that saves you from an accident - or causes one. But we can assert the largest order, the large human values daily, the only order large enough to see. (Michaels 1996, 17)

Jakob felt that Athos, in the four years of living in his room, "gave me another realm to inhabit, big as the globe and expansive as time" (Michaels 1996, 30). But he still felt Bella by his side:

Athos didn't understand, as I hesitated in the doorway, that I was letting Bella enter ahead of me, making sure she was not left behind. I paused when I ate, singing a silent incantation: A bite for me, a bite for you, an extra bite for Bella. "Jakob, you're such a slow eater; you have the manners of an aristocrat." Awake at night, I'd hear her breathing or singing next to me in the dark, half comforted, half terrified that my ear was pressed against the thin wall between the living and the dead, that the vibrating membrane between them was so fragile. I felt her presence everywhere, in daylight, in rooms I knew weren't empty. I felt her touch on my back, my shoulders, my hair. I turned around to see if she was there, to see if she was looking, to see if she was standing guard, though if anything were to happen to me, she wouldn't be able to prevent it. Watching with curiosity and sympathy from her side of the gossamer wall. (Michaels 1996, 23-24)

At the same time, Athos believed that Jakob and he had saved each other. In 1937 Athos had joined a group of archaeologists with the task of preserving waterlogged structures in Biskupin. But soon after deciding to take Jakob home with him, soldiers in Biskupin devastated the former fortifications and houses, also killing five of Athos's colleagues in the nearby forest, and sending the rest to Dachau.

Athos allows for an orphaned Jewish boy to find a substitute home, first in Greece, then in Canada, in the large city of Toronto. The compensation for the loss of his home in Poland in the essential circumstance that allows the orphan to hope for a new beginning. Dalia Kandiyoti, in Contemporary Literature (2004), reads the novel Fugitive Pieces in this light and concludes: 
In Fugitive Pieces, the production of place has everything to do with the destruction of place: through consciousness of the destroyed, whose traces are in invisible corners, cracks, and depths, the displaced many produce a new sense of place for themselves. Invisible places are not only vertical metaphors or devices in the novel to signal deeper truths and meanings than what exist at the surface: digging into place by valorizing its invisible traces reaffirms both the varied lives that were once on the surface and the profundity of the devastation. In this way, Fugitive Pieces can wrest place-based narratives from those who liquidated places and people and attempted to leave no traces. (Kandiyoti 2004, 327)

Also in Toronto Jakob suffers from nightmares. One night, Athos hugs him and says, "Jakob, I long to steal your memories from you while you're sleeping, to syphon off your dreams" (Michaels 1996, 54).

Jakob asks himself whether it is possible to read from someone's face whether they are good or bad, or whether the truth lies on the face:

A child doesn't know much about a man's face but feels what most of us believe all our lives, that he can tell a good face from a bad. The soldiers who performed their duty, handing back to mothers the severed heads of daughters - with braids and hairclips still in place - did not have evil in their faces. There was no perversion of features while they did their deeds. Where was their hatred, their disgust, if not even in their eyes, rolling invisibly back in their sockets, focused on the unanswerable fact of having gone too far? There's the possibility that if one can't see it in the face, then there's no conscience left to arouse. But that explanation is obviously false, for some laughed as they poked out eyes with sticks, as they smashed infants' skulls against the good brick of good houses. For a long time I believed one learns nothing from a man's face. When Athos held me by the shoulders, when he said, "Look at me, look at me" to convince me of his goodness, he couldn't know how he terrified me, how meaningless the words. If truth is not in the face, then where is it? In the hands. In the hands.

I tried to bury images, to cover them over with Greek and English words, with Athos's stories, with all the geologic eras. With the walks Athos and I took every Sunday into the ravines. Years later I would try a different avalanche of facts: train schedules, camp records, statistics, methods of execution. But at night, my mother, my father, Bella, Mones, simply rose, shook the earth from their clothes, and waited. (Michaels 1996, 55)

Jakob is still haunted by memories of the past, and he dreams of Bella's hair, about the day the Nazis stormed into his parents' house:

Sitting at the table, my parents and Bella pretended calm, they who claimed so often to have no courage at all. They remained in their seats as they'd planned they would, if it came to that. The soldiers pushed my father over in his chair. 
And when they saw Bella's beauty, her terrified stillness - what did they make of her hair, did they lift its mass from her shoulders, assess its value; did they touch her perfect eyebrows and skin? What did they make of Bella's hair as they cut it - did they feel humiliated as they fingered its magnificence, as they hung it on the line to dry? (Michaels 1996, 62)

Jakob eventually studied at the University of Toronto, busying himself with literature, history and geography. Later he earned money by translating. He was greatly affected by Athos's death, recalling the following:

On his last night, Athos had come home from giving a lecture on the conservation of Egyptian wood. It was about half past ten. He usually reported some observation of the evening, or even recounted the main details of his talk, but since I'd typed it for him earlier that day the latter was unnecessary, and he was tired. I heated some wine for him then went to bed.

In the morning I found him at his desk. He looked as he often did, asleep in the middle of work. I embraced him with all my strength, again and again, but he would not come back. It is impossible to reach the emptiness in each cell. His death was quiet; rain on the sea. (Michaels 1996, 67)

For many nights after Athos' death, Jakob slept on the floor of his study. He felt that Athos's work on Nazi archaeology was so disturbing that it sucked the life force out of him. Immediately after the war, when they began to get information, he, heavily affected, began collecting documents and asking himself endless questions which he hoped he would be able to answer with the help of everyone else. Jakob felt it was his duty to compile and edit Athos's records of the SS-Ahnenerbe.

In chapter VII, the final chapter of part one, which is titled "The Gradual Instant," we learn that many years after Athos's death and after his divorce from his first wife Alex, Jakob is torn between Canada and Greece. He researches, writes, and publishes works from Athos's legacy. When he meets his second wife Michaela he moves to the Greek island of Idhra, to the home of Athos's parents, and writes down his memories there.

Also with Michaela he still feels the presence of Bella:

Listening to Michaela read, I remember how Bella read poetry; how the yearning in her voice reached me as a child, though I didn't understand the feeling. I realize, half a century after her death, that though my sister never felt herself moving in a man's hands, she must have already loved so deeply, so secretly, that she knew something about the other half of her soul. (Michaels 1996, 171)

However, memories also of another loved one return: 
Each morning I write these words for you all. For Bella and Athos, for Alex, for Maurice and Irena, for Michaela. Here on Idhra, in this summer of 1992, I try to set down the past in the cramped space of a prayer. (Michaels 1996,113)

To gaze into the future, trust, empathy and love are needed. In the novel Fugitive Pieces, Anne Michaels investigates the possibilities of love and faith after the Holocaust. Jakob Beer, who, as a seven-year-old child, was saved from the Nazi slaughter by becoming a fugitive in the Polish forests, where he was saved by the Greek geologist Athos, feels it is his life task to compose a memory of the past and of those he loved.

He understands the power of love precisely because he lost it and then found it again. In the power of love, he wants to live a normal life, like everyone else, after the trauma of the Holocaust. The greatness of the novel lies in its message that we do not need constant evidence of the reality of violence and horror, that a single example suffices. However, we need evidence of the truth of love and its fruit again and again. Contrary to Holocaust literature that focuses on the irreparable breakdown of the psyche, Fugitive Pieces sets as its main motivational aim the contemplating of complete and dubious experiences of healing.

For the writer Anne Michaels it was clearly empathy towards the victims of the Holocaust that dictated the decision to opt for such an extreme traumatic subject. Empathy helps her to discover the possibility of surpassing the usual scheme of irreversible mental breakdown.

Mei-Yu Tsai's "A Poetics of Testimony and Trauma Healing in Anne Michaels's Fugitive Pieces" uses the correct approach - "This essay draws on critical theories of post-Holocaust testimony and postmemory in conjunction with the emerging sociological concept of 'empathetic identification' to investigate the implications of trauma healing in Anne Michaels's Fugitive Pieces" (Tsai 2014, 50).

In her essay the author therefore wishes to investigate how empathetic testimony can help sustain life after a trauma:

As a theoretical starting point in my reading of Fugitive Pieces, I turn to the psychoanalytical theory of testimony and postmemory - especially the works of Dori Laub and Marianne Hirsch - to examine how testimony in association with empathetic identification can help sustain life after massive trauma. (Tsai 2014, 50)

The truth about the reality of atrocity thus opens up the paradoxical possibility of the opposite pole of truth, which empathy and love make possible: the transformational possibility of a Holocaust memorial that will serve future generations.

Only the discovery of the truth about the incompatibility of the evil of the Holocaust can help in the search to heal a sick society. Here we must never ignore 
the other side of the truth, one which Anne Frank so explicitly points out in her diary entry of January 28, 1944:

Going underground or into hiding has become as routine as the proverbial pipe and slippers that used to await the man of the house after a long day at work. There are many resistance groups, such as Free Netherlands, that forge identity cards, provide financial support to those in hiding, organize hiding places and find work for young Christians who go underground. It's amazing how much these generous and unselfish people do, risking their own lives to help and save others.

The best example of this is our own helpers, who have managed to pull us through so far and will hopefully bring us safely to shore, because otherwise they'll find themselves sharing the fate of those they're trying to protect. Never have they uttered a single word about the burden we must be, never have they complained that we're too much trouble. They come upstairs every day and talk to the men about business and politics, to the women about food and wartime difficulties and to the children about books and newspapers. They put on their most cheerful expressions, bring flowers and gifts for birthdays and holidays and are always ready to do what they can. That's something we should never forget; while others display their heroism in battle or against the Germans, our helpers prove theirs every day by their good spirits and affection. (Frank 1995, 132-133)

\section{REAL-LIFE RESCUERS OF JEWS DURING THE HOLOCAUST, AND THEIR MORAL IDENTITY}

Mordecai Paldiel dedicates a paper to the non-Jewish and Jewish "righteous" ones who risked their lives to save endangered Jews. People who decided to save Jews in occupied countries were threatened not only by Germans but also by collaborators in those occupied countries. That is why Paldiel, at the outset of his article, highlights the surprise that any of these Jews and rescuers managed to survive:

Upon reflecting on the immensity of the Holocaust, one sometimes wonders how anyone managed to survive. There are, of course, those who made it by sheer luck; they somehow withstood the terrible inhumanities inflicted on them in the ghettos and concentration camps and miraculously came out alive. At the same time, there is at least an equal number, if not more, of survivors who owe their survival to the good fate of having been extended a helping hand. Some were aided by Jewish networks and individual Jewish rescuers. But in the final account, for the undertaking to have been successful, one also needed the help of non-Jewish rescuers, for they enjoyed more flexibility. Unlike 
Jews, they had not been condemned to death at the outset simply for having been born. (Paldiel 2012, 134)

The collective violence carried out by the Nazi authorities with the cooperation of collaborators of other nationalities also awakened a sense of justice and solidarity in some non-Jewish circles. The unexpected situation of distress awakened strong feelings of compassion and solidarity in good people, especially when this situation demanded immediate action. Among those who helped Jews in need, we find men and women, workers, simple farmers, intellectuals, diplomats, members of left-wing parties from the period before the war, active members of national organizations and some mindful members of Christian churches.

The more painful the testimonies of Jewish survivors of ghettos and concentration camps, the more gratifying the fact that in all countries there were others who strove, to the best of their abilities, and altruistically, to aid Jews. It is significant that there are many more anonymous ones who lost their lives in their attempts to save Jews than there are individuals who, in spite of the great risk, succeeded and survived. ${ }^{10}$ The rescuers aided threatened Jews because they felt an inner need to do so; they helped out of a basic sense of humanity:

Rescuers apparently made little or no conscious decision when they rescued Jews. Conscious decision making entered only at a strategic level, focusing on how best to go about effecting the rescue, rather than on whether to attempt the rescue itself. The conscious element of rescue behavior thus appears to be limited to arranging the specific daily logistics of rescue activity. The initial actions in sheltering Jews were usually described as spontaneous. All our rescuers insisted that they simply saw no other option available to them. Their awareness of life around them made it abundantly clear that there was the option of turning away Jews or of simply doing nothing. They knew that most people did exactly that. But they also knew they could not accept such an option for themselves. The rescuers thus suggest that certain behaviors arise spontaneously, resulting from deep-seated dispositions which form one's central identity. This conclusion, if accurate, suggests that certain behaviors and these may well entail the most significant personal and political choices we make - are not the result of conscious choice at all. (Monroe / Barton / Klingemann 1990,113-114)

10 Since the 1980s, four seminal books about rescuers of Jews have appeared: Samuel P. Oliner in Pearl M. Oliner, The Altruistic Personality: Rescuers of Jews in Nazi Europe (1988); Pearl M. Oliner, Samuel P. Oliner, Lawrence Baron, Lawrence Blum (eds.), Embracing the Other: Philosophical, Psychological, and Historical Perspectives of Altruism (1992); Eva Fogelman, Conscience and Courage: Rescuers of Jews during the Holocaust (1994); Kirsten Renwick Monroe, The Heart of Altruism: Perceptions of a Common Humanity (1998). 
Also Eva Fogelman, in Conscience and Courage: Rescuers of Jews during the Holocaust (1994), seeks an explanation for the question of motivation for the altruistic behaviour of those who rescued Jews. She had discussions with more than three hundred rescuers, including such well-known figures as Miep Gies (known from the diary of Anne Frank), Oskar Schindler and Raoul Wallenberg, as well as lesser-known individuals, such as the Polish minor Stefania Podgorska Burzminska, who hid and saved thirteen Jews in her home when she was not yet eighteen. A valuable general conclusion is that rescuers of Jews did not view their actions as exceptional and heroic but as something self-understood, as something that one must do out of a sense of conscience (Fogelman 1994, 60). When experiencing the extreme circumstances of suffering people, there awoke such a strong empathy in them that they could not remain indifferent. They worked spontaneously, out of compassion, that is, out of an inner sense of moral commitment.

Recently, there has been an increasing number of studies highlighting the role of women as rescuers of their families. In his book Empathy in the Context of Philosophy (2010), Lou Agosta highlights the ethical extent of empathy. In connection with empathy in the circumstances of the Holocaust, meanwhile, Marion A. Kaplan, in her book Between Dignity and Despair: Jewish Life in Nazi Germany (1998), speaks of the reaction of Jews who lives in the extraordinary conditions of Nazi Germany. The author devotes much attention to the extremely important role of Jewish women who, with compassion, dedication and great effort, saved members of their family. Much valuable information about these matters are provided by memoirs, interviews, and letters and diaries of Jewish women who experienced the anxieties of this time. In them, Jewish women highlight the difficulties of helping the family survive, of great emotional engagement, and of resourcefulness in seeking solutions in hopeless situations. ${ }^{11}$

During the period of the rise and consolidation of Hitler's power (19331938), Jewish woman often played a more significant role in saving their families than men did. Women took care of their homes in both a physical and an emotional sense; they calmed terrified children and supported their husbands, who more frequently than they succumbed to frustration and despair. Their encouragement of others was usually linked to the denial of their own worries. There are many known examples of women proving to be rescuers of the family, of having saved their family members from the brutality of authorities, working

11 In her study "Empathic Identification in Anne Michaels's Fugitive Pieces: Masculinity and Poetry after Auschwitz" (2002) Susan Gubar sums up the role of men and women survivors in Anne Michael's novel thus: "Fugitive Pieces can be said to sustain a conventional approach to the catastrophe: Jewish survivors are presented as male protagonists, while female characters play supporting roles as sacrificial muses or nurturing helpmates" (Gubar 2002, 250). 
on the conviction that the authorities would be less harsh on them, since they were women. ${ }^{12}$

\section{CONCLUSION}

Although not all historians have agreed with Philippe Ariès that childhood, as we understand it today, did not exist at all until the Middle Ages, his research remains very important. It opened the possibility of exploring childhood, including the modern romantic idea of childhood innocence, as a social construct that changes over the course of history.

Images of childhood in literature, as well as in the fine arts, arise in particular cultural contexts and in response to specific historical moments. In the history of art, especially visual images of children were often marginalized, since they were rejected as being too sentimental and simple. However, in modern times, the image of the child has become one of the most emotionally powerful and contradictory images in Western consumer culture. Despite changing political, sexual and commercial forms, the image of the child and childhood has retained the message of innocence.

In the figure of the child in the works of Charles Dickens we find the paradoxical phenomenon that the "worshipping" of the romantic cult of childish innocence utterly coincides with the unprecedented industrial exploitation of children. This fact is clearly illustrated in the novel Oliver Twist to be a key cultural icon of Victorian childhood, as well as in the writer's other considered works. Marilyn R. Brown assesses the contradictory attitude towards childhood during Dickens's time thus:

Romanticism's exploration of the subjective self through the idealized state of the child sought a repository of sensitivities and sentiments thought to be lost or blunted in adulthood. While legal reforms (however ineffective they may have been initially) helped attract public opinion to the plight of factory children, capitalism discovered in middle-class children and their parents a readymade consumer class.

12 Among female rescuers or rescuers of Jews are: Klara Baić (Serbia), Jeanne Daman (Belgium), Johanna Eck (Germany), Antonina Gordey (Belarus), Suzanne Spaak (France), Karolina Juszczykowska (Poland), Bronislava Krištopavičienè (Lithuania), Sofia Kritikou (Greece), Maria Agnese Tribbioli (Italy), Caecilia Loots (The Netherlands), Irena Sendler (Poland), Sofka Skipwith (Russia, United Kingdom), Anna Igumnova (Slovakia, Russia), Elisabeta Strul (Romania), Ludviga Pukas (Ukraine), Lois Gunden (United States). On females who have been declared "Righteous among the Nations," see http://www.yadvashem.org/yv/en/exhibitions/righteous-women/index. asp (7.6.2017). 
A burgeoning industry in children's toys, books, magazines, songs, clothes, and advice manuals for parents helped market the child as a symbol of progress and of the future. As state protection and the surveillance provided by its various institutions, including educational, medical, and legal, increasingly diminished the patriarchal power of fathers over their children, the bourgeois ideal of the family and of the protected place of the child within it was magnified. By the end of the century, primary school education was compulsory and free and child protection legislation was enacted.

An ideal of sheltered childhood had become accepted by the middle classes and was finally extended, as a right, to poorer classes as well. Shifting attitudes towards working-class children could be seen in the writings of, among others, Charles Baudelaire, Victor Hugo, and Charles Dickens.

The constructed ideal of childhood innocence was, in many respects, a Victorian defense against advancing awareness of the sexual life of children and adolescents during the period when Freud himself was growing up. (Brown 2004, 454)

The lives of orphans as depicted by Charles Dickens in the Victorian era are difficult, but orphans in the circumstances of the Second World War are even more difficult - they are filled with worse anxiety, distress and suffering, as the proximity to death for those children becomes even more tangible. Many children lost their young lives in the circumstances of the war, but some were fortunate enough to survive. Particularly tragic were the fates of Jewish children who, like the Jewish community as a whole, were exposed to the Holocaust during the Second World War. Most of these children lost their lives. At the beginning of the Second World War in September 1939, the Nazis killed at least six thousand children aged up to sixteen in their program of euthanasia, with some of them being exposed to painful experiments. Because the Nazis wanted to "exterminate" the Jews, they were utterly merciless. In the so-called "final solution" the Nazis killed 1.2 to 1.5 million Jewish children. In the many narratives, memoirs and diaries about the Holocaust, however, we can discover the surprising phenomenon that some Jewish children, despite being unprotected and in a state of weakness and, despite the brutality of evil that threatened them, maintained a strong hope or faith in the final victory of the good (see the diaries of Anne Frank and Helen Berr, among others).

While most Jewish children lost their lives during the Second World War, many of them were orphaned due to the Holocaust. In her novel Fugitive Pieces, Canadian writer Anne Michaels lays out one such shocking story. In it, she gives a voice to the Jewish boy Jakob, whose parents and sister were killed in Poland and who, frightened and fleeing, happens to be noticed in the woods by the Greek geologist Athos. Without hesitating, Athos decides to help the poor child and to save him from mortal danger, even if it means risking his own life. 
The writer Anne Michaels in her novel Fugitive Pieces asks where memory can help overcome the traumas that have marked the orphaned Jakob throughout his life. What sort of relationship must the afflicted person have towards the brutal past, to death, to those who perpetrated the evil? Is it possible to forgive the perpetrators if their victims are already dead and must therefore remain silent? Is it possible to heal the deep and wounded memory through love and thus give rise to a new life? Is it possible to take leave of the dead in order to remain with the living in a different, less painful way? Can trauma at least slightly be alleviated through the memory of the happy childhood that Jakob Beer spent in the circle of his Jewish family somewhere in Poland? How can the loving, moral and emotional support from generous people help victims overcome trauma and return to a "normal" life?

In her novel Fugitive Pieces, Anne Michaels describes the contrast between the brutality of the Holocaust and the sacrificial benevolence of the rescuer of the surviving boy in the figure of the foreign intellectual. She puts the story into the broader framework of "typical" stories about saving an orphan. In their article "Holocaust Literature and Historiography in Anne Michaels' Fugitive Pieces" (2013), Victoria Nesfield and Philip Smith argue:

Michaels' Fugitive Pieces makes no claim to be a truthful representation of the author's life and experience. It does, however, follow many of the conventions of the Shoah genre despite it not being a Shoah testimony in the style of most others. Michaels seems at times to be constructing a "typical" survivor's tale through reference to other genuine testimony. Michaels' literature shares with the work of Wilkomirski and Defonseca the use of the Jewish orphaned child victim of the Shoah as a channel for the narrative. This motif can most obviously be traced back to Elie Wiesel's trajectory (even though Wiesel did not lose his father until the end of his experience and survived in the camps ostensibly as an adult despite being only 15). (Nesfield and Smith 2013, 17-18)

On a Greek island, Jakob Beer reveals to his rescuer Athos that he cannot longer remember the faces of his mother, his father and his sister Bella. However, he can clearly remember their expressions: "I can no longer remember their faces, but I imagine expressions trying to use up a lifetime of love in the last second. No matter the age of the face, at the moment of death a lifetime of emotion still unused turns a face young again" (Michaels 1996, 18).

Jakob knows how central a place love had in the lives of his intimates who died and what a stark contrast this was to the unthinkable horror of the evil that befell them. The traumatic event of his mother's and his father's murder means that fear accompanies him for a long time on the Greek island of Zakynthos. The only person he completely trusts is Athos, and he believes he "was being 
offered a second history" (Michaels 1996,20), if only he is strong enough to accept it. He has a very strong relationship to and devotion for Athos, who helps him overcome his fear and to awaken the faith that there is "an invisible world, just as real as what's evident" (Michaels 1996, 49).

In this world, even his loved ones that the war took away are alive. Jakob does not believe that they are buried in the earth, for he can feel them by his side:

The dead passed above me, weird haloes and arcs smothering the stars. The trees bent under their weight. I'd never been alone in the night forest, the wild bare branches were frozen snakes. The ground tilted and I didn't hold on. I strained to join them, to rise with them, to peel from the ground like paper ungluing at its edges. I know why we bury our dead and mark the place with stone, with the heaviest, most permanent thing we can think of: because the dead are everywhere but the ground. (Michaels 1996,12)

Nevertheless, it is not until many years later that Jakob senses he must somehow leave the dead behind in order to be able to write down the past, think about it, and devote himself to it: "Each morning I write these words for you all. For Bella and Athos, for Alex, for Maurice and Irena, for Michaela. Here on Idhra, in this summer of 1992, I try to set down the past in the cramped space of a prayer" (Michaels 1996, 171).

\section{BIBLIOGRAPHY AND WORKS CITED}

Agosta, Lou. 2010. Empathy in the Context of Philosophy. London: Palgrave Macmillan.

Anderson, Roland F. Structure, Myth, and Rite in "Oliver Twist". Studies in the Novel (1986): 18/3: 238-257.

Anderson, Mark M. 2007. The Child Victim as Witness to the Holocaust: An American Story? Jewish Social Studies (2007): New Series 14/1: 1-22.

Ariès, Philippe. 1960. L'Enfant et la vie familiale sous l'Ancien Régime. Paris: Seuil. Ariès, Philippe. 1962. Centuries of Childhood: A Social History of Family Life. Trans. Robert Baldick. New York: Vintage Books.

Attebery, Louie W. The American West and the Archetypal Orphan. Western American Literature (1970): 5/3: 205-2017.

Banerjee, Jacqueline. 1996. Through the Northern Gate: Childhood and Growing Up in British Fiction 1719-1901. New York: Peter Lang.

Baron, Lawrence. The Holocaust and Human Decency: A Review of Research on the Rescue of Jews in Nazi Occupied Europe. Humboldt Journal of Social Relations (1985/86): 13/1-2: 237-251. 
Berger, Alan L. and Gloria L. Cronin (eds.). 2004. Jewish American and Holocaust Literature: Representation in the Postmodern World. New York, NY: State University of New York Press.

Berger, Alan L. 2004. Hidden Children: The Literature of Hiding. In: Alan L. Berger and Gloria L. Cronin (eds.), Jewish American and Holocaust Literature: Representation in the Postmodern World. New York, NY: State University of New York Press. 13-30.

Brown, Marilyn R. 2004. Images of Childhood. In: Paula S. Faas (ed.), Encyclopedia of Children and Childhood: In History and Society, I-III (Volume I). New York, NY: Macmillan Reference USA. 449-462.

Brunet, Guy. 2004. Orphans. In: Paula S. Faas (ed.), Encyclopedia of Children and Childhood: In History and Society, I-III. New York, NY: Macmillan Reference USA. 640-643.

Cavanagh, Michael E. Rediscovering Compassion. Journal of Religion and Health (1995): 34/4: 317-327.

Chlebek Diana. 2011. DICKENS, CHARLES David Copperfield (1849-1850). In: Jennifer McClinton-Temple (ed.), Encyclopedia of Themes in Literature. New York, NY: Fact On File. 334-337.

Chlebek Diana. 2011. DICKENS, CHARLES Oliver Twist (1837-1839). In: Jennifer McClinton-Temple (ed.), Encyclopedia of Themes in Literature. New York, NY: Fact On File. 341-344.

Cornell, Elizabeth. 2011. FAULKNER, WILLIAM Light in August (1932). In: Jennifer McClinton-Temple (ed.), Encyclopedia of Themes in Literature. New York, NY: Fact On File. 425-429.

Coveney, Peter. 1967. The Image of Childhood: The Individual and Society: A Study of the Theme in English Literature. London: Penguin Books.

Cretzmeyer, Stacy. 1999. Your Name is Renée: Ruth Kapp Hartz's Story as a Hidden Child in Nazi-Occupied France. New York: Oxford University Press.

Cunningham, Hugh. 1995. Children and Childhood in Western Society since 1500. London: Longman.

DeRouen, Anita and Gulshan Taneja. 2011. BYRON, GEORGE GORDON BYRON, LORD Don Juan (1817-1824). In: Jennifer McClinton-Temple (ed.), Encyclopedia of Themes in Literature. New York, NY: Fact On File. 243-246.

Dickens, Charles. 2008. Oliver Twist. Edited by Kathleen Tillotson, Introduction and Notes by Stephen Gill. Oxford: Oxford University Press. (Oxford World's Classics).

Ellison, David. 2004. Ethics and Aesthetics in European Modernist Literature: From the Sublime to the Uncanny. Cambridge: Cambridge University Press. 
Estrin, Barbara L. Ending in the Middle: Revisioning Adoption in Binjamin Wilkomirski's "Fragments" and Anne Michaels's "Fugitive Pieces". Tulsa Studies in Women's Literature (2002): 21/2: 275-300.

Faas, Paula S. (ed.), 2004. Encyclopedia of Children and Childhood: In History and Society, I-III. New York, NY: Macmillan Reference USA.

Fensham, F. Charles. Widow, Orphan, and the Poor in Ancient Near Eastern Legal and Wisdom Literature. Journal of Near Eastern Studies (1962): 21/2: 129-139.

Fogelman, Eva. 1994. Conscience and Courage. Rescuers of Jews during the Holocaust. New York: Doubleday Anchor.

Frank, Anne. 1993. A Diary of a Young Girl. New York: Bantam Books.

Friedländer, Saul. 1979. When Memory Comes. Trans. Helen R. Lane. New York: Farrar Straus Giroux.

Geest, Sjaak van der. Orphans in Highlife: An Anthropological Interpretation. History in Africa (2004): 31: 425-440.

Georgieva, Margarita. 2011. Childhood. In: Jennifer McClinton-Temple (ed.), Encyclopedia of Themes in Literature. New York, NY: Fact On File. 10-12.

Gille, Elisabeth. 1998. Shadows of a Childhood. Trans. Linda Coverdale. New York: The New Press.

Gordon, John. 2011. Sensation and Sublimation in Charles Dickens. New York: Palgrave Macmillan.

Gribble, Jennifer. Why the Good Samaritan Was a Bad Economist: Dickens' Parable for Hard Times. Literature and Theology (2004): 18/4: 427-441.

Gubar, Susan. Empathic Identification in Anne Michaels's Fugitive Pieces: Masculinity and Poetry after Auschwitz. Signs (2002): 28/1: 249-276.

Immel, Andrea and Michael Witmore (ed.). 2006. Childhood and Children's Books in Early Modern Europe, 1550-1800. New York / London: Routledge.

Jaeger. C. Stephen. 2012. Enchantment: On Charisma and the Sublime in the Arts of the West. Philadelphia: University of Pennsylvania Press.

James, Scott M. Good Samaritans, Good Humanitarians. Journal of Applied Philosophy (2007): 24/3: 238-254.

Kaplan, Marion A. 1998. Between Dignity and Despair: Jewish Life in Nazi Germany. Oxford: Oxford University Press. (Studies in Jewish History).

Katz, Steven T., Shlomo Biderman and Gershon Greenberg (ed.). 2007. Wrestling with God: Jewish Theological Responses during and after the Holocaust. Oxford: Oxford University Press.

König, Eva. 2014. The Orphan in Eighteenth-Century Fiction: The Vicissitudes of the Eighteenth-Century Subject. Basingstoke: Palgrave Macmillan.

Manning, Erin. Beyond Accommodation: National Space and Recalcitrant Bodies. Alternatives: Global, Local, Political (2000): 25/1: 51-74 
Marten, James (ed.). 2002. Children and War: A Historical Anthology. Foreword by Robert Coles. New York / London: New York University Press.

McClinton-Temple, Jennifer (ed.). 2011. Encyclopedia of Themes in Literature. New York, NY: Fact On File.

McClinton-Temple, Jennifer (ed.), 2011. DICKENS, CHARLES Great Expectations (1860-1861). In: Jennifer McClinton-Temple (ed.), Encyclopedia of Themes in Literature. New York, NY: Fact On File. 337-341.

Michaels, Anne.1996. Fugitive Pieces. A Novel. 1st ed. New York: Vintage Books. A Division of Random House, Inc.

Michaels, Anne. 2017. Ubežni delci. Translated by Teja Bivic. Ljubljana: Modrijan. Monroe, Kristen Renwick, Michael C. Barton and Ute Klingemann. Altruism and the Theory of Rational Action: Rescuers of Jews in Nazi Europe. Ethics (1990): 101: 103-122.

Monroe, Kristen Renwick. 1998. The Heart of Altruism: Perceptions of Common Humanity. Princeton: Princeton University Press.

Nelson, Cassandra. 2011. TWAIN, MARK Adventures of Huckleberry Finn (1884; 1885 [U.S.]. V: Jennifer McClinton-Temple (ed.), Encyclopedia of Themes in Literature. New York, NY: Fact On File. 1082-1085.

Nesfield, Victoria and Philip Smith. Holocaust Literature and Historiography in Anne Michaels' Fugitive Pieces. Journal of European Studies (2013): 43/1: 14-26.

Oliner Samuel P. and Pearl M. Oliner. 1988. The Altruistic Personality: Rescuers of Jews in Nazi Europe. New York: Free Press.

Paldiel, Mordecai. Righteous Gentiles and Courageous Jews: Acknowledging and Honoring Rescuers of Jews. French Politics, Culture and Society (2012): 30/2: 134-149.

Partee, Morriss Henry. 2006. Childhood in Shakespeare's Plays. New York: Peter Lang Publishing.

Pollock, Linda A. 1983. Forgotten Children: Parent-Child Relations from 1500 to 1900. Cambridge: Cambridge University Press.

Radhwi, Mariam. 2011. BLAKE, WILLIAM, Songs of Innocence and Experience (1789, 1794). In: Jennifer McClinton-Temple (ed.), Encyclopedia of Themes in Literature. New York, NY: Fact On File. 216.

Radhwi, Mariam. 2011. INNOCENCE AND EXPERIENCE in Songs of Innocence and Experience. In: Jennifer McClinton-Temple (ed.), Encyclopedia of Themes in Literature. New York, NY: Fact On File. 216.

Rose, Lionel. 1991. The Erosion of Childhood: Child Oppression in Britain 18601918. London and New York: Routledge.

Roukema, Riemer. The Good Samaritan in Ancient Christianity. Vigiliae Christianae (2004): 58/1: 56-74. 
Sorop, Aloisia. 2011. TWAIN, MARK, The Adventures of Tom Sawyer (1876). In: Jennifer McClinton-Temple (ed.), Encyclopedia of Themes in Literature. New York, NY: Fact On File. 1085.

Stearns, Peter N. Childhood in World History. New York / London: Routledge.

Tsai, Mei-Yu. 2014. A Poetics of Testimony and Trauma Healing in Anne Michaels's Fugitive Pieces. Shofar (2006): 32/3: 50-71.

Welch, John W. The Good Samaritan: A Type and Shadow of the Plan of Salvation. Brigham Young University Studies (1999): 38/2: 50-115.

Wilkomirski, Binjamin. 1997. Fragments: Memories of a Wartime Childhood. New York: Schocken Books.

Wiman, Christian. Fugitive Pieces. Poetry (2001): 179/2: 90-102.

Wolf, Diane L. 2007. Beyond Anne Frank: Hidden Children and Postwar Families in Holland. Berkeley / Los Angeles / London: University of California Press.

Zalar, Jeffrey T. 2004. Holocaust. In: Paula S. Faas (ed.), Encyclopedia of Children and Childhood: In History and Society, volume II. New York, NY: Macmillan Reference USA. 431-334.

Zmora, Nurit. 2004. Orphanages. In: Paula S. Faas (ed.), Encyclopedia of Children and Childhood: In History and Society, I-III. New York, NY: Macmillan Reference USA. 638-640.

Translated from Slovenian

Irena Avsenik Nabergoj,

University of Ljubljana, ZRC SAZU, Univerza v Novi Gorici irena.avsenik-nabergoj@guest.arnes.si

\section{Otroci brez otroštva: čustvovanje osirotelih otrok in liki njihovih rešiteljev $\mathbf{v}$ izbranih delih angleške in kanadske književnosti}

Prispevek obravnava literarne opise družbenih, političnih, kulturnih in verskih okoliščin, v katerih so se znašli otroci, ki so že ob rojstvu ali pozneje v otroštvu izgubili enega ali oba starša. Kot najšibkejši členi družbe so bili izpostavljeni grožnjam, izkoriščanju in nasilju, a so imeli srečo, da jih je rešil kak sorodnik ali kakšna druga sočutna in dobrohotna oseba. Ob ugotovitvi, da opise odnosa med otrokom - siroto, ki je v smrtni nevarnosti -, in rešiteljem, ki se večinoma pojavi nepričakovano, zasledimo $\mathrm{v}$ pripovedih vseh časov in da zato lahko govorimo o 
arhetipu razmerja med otrokom-siroto in rešiteljem, se članek osredotoča predvsem na tri romane angleškega pisatelja Charlesa Dickensa Oliver Twist (18371839), David Copperfield (1849-1850) in Great Expectations (1860-1861) ter roman sodobne kanadske pisateljice Anne Michaels Fugitive Pieces (1996). Charles Dickens je dosegel sloves pisatelja klasika z izvirnimi literarnimi prikazi otroka - sirote - v okoliščinah grobega kapitalizma viktorijanske dobe 19. stoletja. Izvirnost odlikuje tudi Anne Michaels, ki v romanu Fugitive Pieces slika skrajno travmatične okoliščine, kakršnim je izpostavljen judovski deček, potem ko Nemci sredi morije holokavsta ubijejo njegove starše. Vse osrednje otroške like iz skrajnih položajev rešijo plemeniti ljudje, s tem pa je poudarjena osrednja ideja obeh izbranih avtorjev: da zlo ne more premagati dobrega. Rešitelji svojo nesebično odločenost, da rešijo nemočne in nezaščitene otroške žrtve nasilja iz življenjsko nevarnih okoliščin, doživljajo kot samoumevni moralni imperativ. Charles Dickens in Anne Michaels sta s svojimi poglobljenimi in močno občutenimi opisi spominov na travme, ki so jih njuni osrednji literarni liki uspešno premagovali ob pomoči sočutja in solidarnosti, prihodnjim generacijam zapustila testament upanja proti upanju.

Ključne besede: Charles Dickens, čustva, spomini, Anne Michaels, holokavst, osiroteli otroci, rešitelji, travma, posvojitev, zmaga dobrega. 